
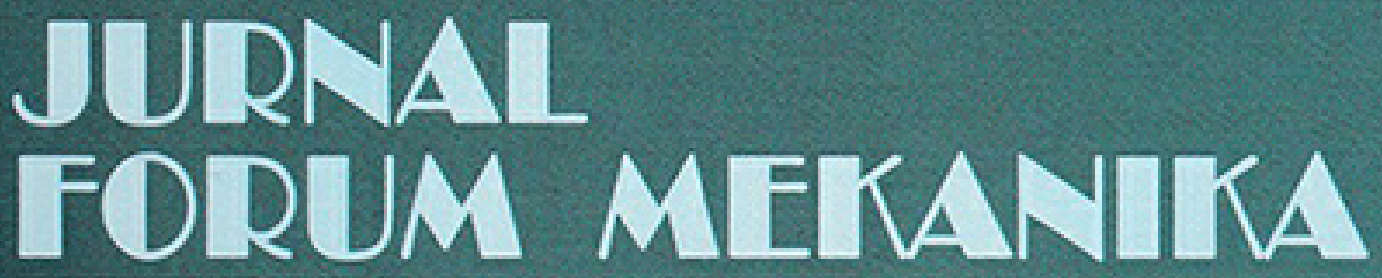

Volume 6 - Nomor 2 November 2017 ISSN : 2356-1491

ANALISIS RUMAH KABEL BAWAH TANAH PADA PROYEK PEKERJAAN JARINGAN UTILITAS SKTT 150 KV PLUMPANG - GAMBIR DYAH PRATIWI KUSUMASTUTI; IRMA SEPRIYANNA

STUDI KOMPARASI ANTARA PRACETAK MASIF DAN FLY SLAB STUDI KASUS: STRUKTUR GEDUNG RUSUNAWA SURAKARTA BUDI WICAKSONO

SISTEM DRAINASE ALIRAN BAWAH TANAH UNTUK DAERAH RAWAN LONGSOR (STUDI KASUS SUB DAS SUNGAI CIKAPUNDUNG, BANDUNG) ENDAH LESTARI

ANALISA STATISTIK DEBIT BANIIR DAN DEBIT ANDALAN SUNGAI KOMERING SUMATERA SELATAN DEVITA MAYASARI

STUDI EKSPERIMENTAL KUAT LENTUR BAJA PROFIL I KOMPAK SIMETRIS GANDA BERDASARKAN RSNI 03-1729-201X

DICKI DIAN PURNAMA; AKHMAD AMINULLAH; MUSLIKH

PENGGUNAAN PASIR LAUT TERHADAP KUAT TEKAN BETON KOTA BENGKULU TOMMYIDUWIN

ANALISA PENGARUH ADMIXTURE TERHADAP ABU TERBANG (FLY ASH) DAN BOTTOM ASH

TRI YUHANAH; NOVIA ADE MANDASARI

ANALISA KINERJA PERSIMPANGAN BERSINYAL PADA PERSIMPANGAN ANGKATAN 66 DAN RUAS JALAN R. SOEKAMTO KOTA PALEMBANG YULES PRAMONA ZULKARNAIN; IRMA INDRIANI 


\title{
ANALISA KINERJA PERSIMPANGAN BERSINYAL PADA PERSIMPANGAN ANGKATAN 66 DAN RUAS JALAN R. SOEKAMTO KOTA PALEMBANG
}

\author{
YULES PRAMONA ZULKARNAIN \\ Teknik Sipil/Fakultas Teknik, Universitas Tridinanti Palembang \\ E-mail : Jules_praz@yahoo.com \\ IRMA INDRIANI \\ Teknik Arsitektur/Fakultas Teknik, Universitas Tridinanti Palembang \\ E-mail : irmadani@yahoo.com
}

\begin{abstract}
Abstrak
Transportasi merupakan sarana yang sangat penting dan strategis untuk memperlancar pergerakan dalam upaya pemenuhan kebutuhan masyarakat. Perencanaan dan pembangunan sarana dan prasarana transportasi, sangat mempengaruhi dalam menentukan peningkatan pertumbuhan perekonomian dalam menunjang pencapaian sasaran pembangunan. Dampak nyata yang terjadi sebagai akibat dari pesatnya pertumbuhan ekonomi ,pertambahan jumlah penduduk dan adanya perubahan tata guna lahan berpengaruh pada kinerja persimpangan dan ruas jalan terutama masalah kemacetan, tundaan, peluang antrian dan persoalan lainnya. Berdasarkan pada hasil analisis perhitungan yang telah dilakukan dengan menggunakan metode manual kapasitas jalan Indonesia (MKJI), kapasitas simpang Angkatan 66 Kota Palembang pada kondisi puncak pagi adalah 3007 smp/jam, pada kondisi puncak siang adalah 2875 smp/jam dan pada kondisi puncak sore adalah 2997 smp/jam.Tingginya pergerakan arus lalu lintas kendaraan pada persimpangan Angkatan 66 dan ruas jalan $R$. Soekamto mengindikasikan bahwa tingkat pelayanan sudah tidak memadai untuk memenuhi kebutuhan lalu lintas, hal ini dapat dilihat dari Tingkat pelayanan atau kinerja (Level of Service /LOS) terendah pada persimpangan Jl. Angkatan 66 dan ruas jalan $R$. Soekamto berada dilevel C $(0,7908)$ dan D $(0,889)$ dimana arus mulai tidak stabil, kecepatan operasi menurun relative cepat akibat hambatan yang timbul. Maka untuk mengatasi permasalahan tersebut alternatif pelebaran jalan atau pembangunan jembatan layang (fly over) dan pengaturan lalu lintas berupa manajemen rekayasa lalu lintas sudah perlu dilaksanakan.
\end{abstract}

Kata kunci : Kapasitas, Tingkat Pelayanan, Persimpangan, Ruas Jalan

\begin{abstract}
Transportation is a very important and strategic means to facilitate the movement in an effort to meet the needs of the community. Planning and construction of transportation facilities and infrastructure, greatly influence in determining the increase of economic growth in supporting the achievement of development targets. The real impact that occurs as a result of rapid economic growth, population growth, and changes in land use affects the performance of intersections and roads, especially the problem of congestion, delays, queues opportunities and other issues. Based on the result of calculation analysis which have been done by using Indonesian Highway Capacity Manual method (IHCM), capacity of intersection of Angkatan 66 Palembang on the condition of the morning peak was $3007 \mathrm{smp} /$ hour at peak lunch was $2875 \mathrm{smp} /$ hour and the afternoon peak is $2997 \mathrm{smp} /$ hour. The high movement of vehicular traffic flow at the intersection of Angkatan 66 and the road R. Soekamto indicates that the level of service is not sufficient to meet traffic needs, this can be seen from the Lower level of service or performance (Level of Service / LOS) at the intersection Angkatan 66 and the road R. Soekamto C $(0,7908)$ and $D(0,889)$ are at the level where the current begins unstable operation speed relatively quick decline due to the obstacles that arise. So to overcome the problem of alternative road widening or construction of fly over (fly over) and traffic management in the form of traffic engineering management has to be implemented.
\end{abstract}

Keywords: Capacity, Level of Service, Intersection, Roads 


\section{Pendahuluan}

\section{Latar Belakang}

Perencanaan dan pembangunan sarana dan prasarana transportasi, sangat mempengaruhi dan menentukan peningkatan pertumbuhan perekonomian dalam menunjang pencapaian sasaran pembangunan dan hasil-hasilnya, yang berdampak nyata pada perubahan yang konstruktif dalam masyarakat disemua aspek kehidupan. Selain itu, situasi dan kondisi lingkungan mengalami perubahan yang fundamental ke arah peningkatan yang lebih baik dan lebih maju, sehingga mampu meningkatkan taraf hidup masyarakat luas dan memperkuat stabilitas nasional.

Persimpangan merupakan pusat konflik dengan parameter semakin rapat jaringan jalan yang ada membuat mobilitas penduduk semakin tinggi dan membuat kota tumbuh lebih cepat, dengan semakin meningkatnya kepadatan penduduk maka meningkat pula kendaraan pribadi semakin padat pada ruas jalan kota. Persimpangan adalah bagian dari sistem jaringan jalan, yang secara umum kapasitas persimpangan dapat dikontrol dengan mengendalikan volume lalu-lintas dalam sistem jaringan tersebut.

Kota Palembang dengan luas wilayah 470,236 $\mathrm{Km}^{2}$ dan mempunyai 16 kecamatan yang merupakan ibukota provinsi Sumatera selatan juga merasakan dampak dari hal tersebut. Kesemerawutan, ketidakefektifan dan ketidaknyamanan angkutan umum pada simpang Jl. Angkatan 66 - Jl. Basuki Rahmat Kota Palembang merupakan permasalahan serius yang harus segera di atasi.

Oleh karena itu, untuk mengatasi permasalahanpermasalahan tersebut di atas diperlukan suatu metode untuk mengetahui seberapa besar pengaruh kondisi existing jalan terhadap perubahan pergerakan arus lalu-lintas. Pengaruh adanya pergerakan maupun jumlah penduduk terhadap pergerakan yang paling awal dapat diidentifikasikan adalah besarnya jumlah pergerakan kendaraan yang melalui suatu ruas jalan maupun pada persimpangan.

Karakteristik jaringan jalan di kota Palembang yang sebagian besar terdapat persimpangan dimana dengan keberadaanya itu sendiri sudah menimbulkan konflik pergerakan, sebagai sumber kemacetan dan daerah rawan kecelakaaan. Tingginya tundaan pergerakan kendaraan yang menuju kawasan persimpangan tersebut menambah parah kemacetan dan kesemrawutan yang terjadi pada persimpangan dan ruas jalan R. Soekamto. Untuk itu perlu dilakukan pengaturan dan pengendalian persimpangan dan ruas jalan untuk menciptakan kawasan persimpangan yang bekerja sesuai dengan fungsi operasionalnya. Berdasarkan permasalahan tersebut diatas, maka pada penelitian ini akan dianalisis dan dibahas mengenai kinerja dan kapasitas ruas Jalan R. Soekamto berdasarkan kebutuhan (demand) dan pemenuhan (supply) transportasi saat ini serta tingkat pelayanan persimpangan bersinyal pada simpang Angkatan 66 Kota Palembang untuk kondisi saat ini.

\section{Landasan Teori}

\section{Gambaran Umum Kota Palembang}

Kota Palembang terletak antara $2^{0} 52^{\prime}$ sampai $3^{0} 5^{\prime}$ LS dan $104^{0} 37^{\prime}$ sampai $104^{0} 52^{\prime}$ BT dengan ketinggian rata-rata 12 meter dari permukaan laut. Disebelah utara, sebelah timur dan sebelah barat berbatasan dengan Kabupaten Banyu Asin, sebelah selatan berbatasan dengan Kabupaten Muara Enim dan Kabupaten Ogan Ilir. Sejak tahun 2007 Kota Palembang terdiri dari 16 kecamatan dan 107 kelurahan. Berdasarkan PP No. 23 tahun 1998 luas wilayah Palembang adalah 400,61 $\mathrm{km}^{2}$, dengan jumlah penduduk kota Palembang saat ini mencapai 1,8 juta jiwa lebih.

\section{Sarana dan Prasarana Persimpangan Jalan}

1. Sarana Persimpangan Jalan Raya.

Unsur sarana terdiri dari :

a. Heavy vehicle yang berupa kendaraan berat yakni bus, truk. (HV)

b. Llight vehicle berupa kendaraan ringan. (LV)

c. Motor cycle berupa sepeda motor, bajai. (MC)

d. Non kendaraan bermotor berupa sepeda, gerobak. (UM)

2. Prasarana Persimpangan Jalan Raya.

a. Jalan raya, bangunan dan konstruksi pelengkap antara lain :

1) Bangunan jalan berupa jalan layang, jalan tol, terowongan

2) Kontruksi pelengkap antara lain: (pagar, drainase, trotoar)

b. Tanda peringatan dan kelengkapan antara lain

1) Rambu-rambu lalu-lintas

2) Lampu-lampu penerangan

c. Faktor pendukung antara lain : terminal dan tempat parkir serta halte bus.

\section{Persimpangan}

Persimpangan merupakan tempat yang rawan terhadap kemacetan karena sering terjadinya gap/konflik antara kendaraan. Konflik adalah pertemuan dua lintasan kendaraan, ada beberapa macam gerakan/ pertemuan kendaraan adalah :

1. Diferging conflict, yaitu gerakan yang memisah pada lintasan.

2. Merging conflict, yaitu gerakan menggabung dua lintasan dan arah berlainan.

3. Through flow conflict, yaitu titik perpotongan dua lintasan lurus, tegak lurus.

4. Turning flow conflict, yaitu titik perpotongan lintasan lurus dan lintasan belok.

Ada beberapa macam teknik pengendalian lalulintas yang dikenal di Indonesia, adalah: 
a. Vield control : Arus lalu-lintas tertentu diberikan prioritas untuk tidak perlu berhenti penuh.

b. Stop control : Arus lalu-lintas harus berhenti penuh terlabih dahulu dibelakang stop line senbelum melewati persimpangan.

c. Signal control : Persimpangan dikendalikan lampu lalu-lintas/ traffic linght.

Di Indonesia, metoda analisa dengan prioritas tidak berdasarkan celah (gap acceptence), melainkan berdasarkan pada kapasitas jalan yang didapat dari data empiris yang dikumpulkan untuk nilai derajat kejenuhan (ds= degree of saturation) di bawah $0,8-$ 0,9 . analisa simpang ini lebih dapat diandalkan bila dibandingkan dengan nilai $d s$ di atasnya ${ }^{[1]}$.

\section{Tipe / Jenis Simpang}

1. Simpang Tak Bersinyal

Pada umumnya simpang tak bersinyal dengan pengaturan hak jalan (perioritas dari sebelah kiri) digunakan di daerah pemukiman perkotaan dan daerah yang arus lalu-lintasnya rendah. Ada beberapa faktor yang mempengaruhi kinerja simpang tak bersinyal.

Ada beberapa faktor yang mempengaruhi kinerja simpang dalam perhitungan pada antara lain ${ }^{[1]}$.
a. Geometrik simpang
b. Arus lalu-lintas.
c. Kondisi lingkungan.
d. Kapasitas.

2. Simpang Bersinyal

Penerapan sinyal lalu-lintas dipersimpangan dipergunakan untuk beberapa alasan, antara lain:

a. Untuk menghindari kemacetan simpang akibat adanya konflik arus lalu-lintas, sehingga kapasitas tertentu dapat dipertahankan, bahkan kondisi jam puncak.

b. Untuk mengurangi jumlah kecelakaan lalulintas akibat tabrakan kendaraan dari arah yang berlawanan.

\section{Satuan Mobil Penumpang (smp)}

Satuan mobil penumpang adalah suatu satuan yang dapat dipakai dalam perencanaan lalu-lintas. Untuk kendaraan ringan $(L V)$ nilai smp 1,0 untuk kendaraan berat $(H V)$ nilai smp 1,3 dan sepeda motor $(M C)$ nilai smp 0,5. Berbagai jenis kendaraan diekivalensikan ke satuan mobil penumpang dengan menggunakan faktor ekivalensi mobil penumpang $(\text { emp })^{[1]}$.

\section{Tingkat Pelayanan / Level Of Services (LOS)}

Tingkat pelayanan untuk setiap tipe dari fasilitas lalu-lintas yang akan digunakan dalam parameter analisis, yang disimpulkan dengan huruf A sampai dengan huruf F, dimana Level of Service (LOS) A menunjukkan kondisi operasional terbaik, dan LOS F paling jelek. Di Indonesia kondisi pada tingkat pelayanan (LOS) diklasifikasikan seperti berikut ini:
Tabel 1. Tingkat Pelayanan Simpang

\begin{tabular}{|c|c|c|c|}
\hline $\begin{array}{c}\text { Tingkat } \\
\text { Pelayanan }\end{array}$ & $\begin{array}{c}\text { Kecepatan } \\
\text { Rata-rata }\end{array}$ & $\mathrm{V} / \mathrm{C}$ & Deskripsi \\
\hline A & $>50$ & $\begin{array}{c}< \\
0.40\end{array}$ & $\begin{array}{l}\text { Arus bebas } \\
\text { bergerak (aliran } \\
\text { lalu-lintas bebas, } \\
\text { tanpa hambatan, } \\
\text { pengemudi bebas } \\
\text { memilih } \\
\text { kecepatan sesuai } \\
\text { batas yang } \\
\text { ditentukan) }\end{array}$ \\
\hline B & $>40$ & $\begin{array}{c}< \\
0.58\end{array}$ & $\begin{array}{l}\text { Arus stabil, tidak } \\
\text { bebas (arus lalu- } \\
\text { lintas baik, } \\
\text { kemungkinan } \\
\text { terjadi } \\
\text { perlambatan, } \\
\text { kecepatan operasi } \\
\text { mulai dibatasi, } \\
\text { mulai ada } \\
\text { hambatan dari } \\
\text { kendaraan lain) }\end{array}$ \\
\hline $\mathrm{C}$ & $>32$ & $\begin{array}{c}< \\
0.80\end{array}$ & $\begin{array}{l}\text { Arus stabil, } \\
\text { kecepatan terbatas } \\
\text { (arus lalu-lintas } \\
\text { masih baik dan } \\
\text { stabil dengan } \\
\text { perlambatan yang } \\
\text { dapat diterima), } \\
\text { hambatan dari } \\
\text { kendaraan lain } \\
\text { makin besar }\end{array}$ \\
\hline $\mathrm{D}$ & $>27$ & $\begin{array}{c}< \\
0.90\end{array}$ & $\begin{array}{l}\text { Arus mulai tidak } \\
\text { stabil (mulai } \\
\text { dirasakan } \\
\text { gangguan dalam } \\
\text { aliran, aliran } \\
\text { mulai tidak baik), } \\
\text { kecepatan operasi } \\
\text { menurun relative } \\
\text { cepat akibat } \\
\text { hambatan yang } \\
\text { timbul }\end{array}$ \\
\hline $\mathrm{E}$ & $>24$ & $\begin{array}{c}< \\
1.00\end{array}$ & $\begin{array}{l}\text { Arus yang tidak } \\
\text { stabil kadang } \\
\text { macet (volume } \\
\text { pelayanan berada } \\
\text { pada kapasitas } \\
\text { aaliran tidak } \\
\text { stabil) }\end{array}$ \\
\hline $\mathrm{F}$ & $<24$ & $\begin{array}{c}> \\
1.00\end{array}$ & $\begin{array}{l}\text { Macet, antrian } \\
\text { panjang (volume } \\
\text { kendaraan } \\
\text { melebihi } \\
\text { kapasitas, aliran } \\
\text { telah mengalamai } \\
\text { kemacetan) }\end{array}$ \\
\hline
\end{tabular}

Sumber: MKJI, 1997

\section{Kondisi Lingkungan}

Data lingkungan diperlukan untuk perhitungan kapasitas jalan dan data masukan yang diperlukan adalah sebagai berikut:

1. Kelas ukuran kota 
Tabel 2. Kelas Ukuran Kota

\begin{tabular}{|c|c|}
\hline Ukuran Kota & Jumlah Penduduk (juta) \\
\hline Sangat kecil & $<0,1$ \\
Kecil & $0,1-0,5$ \\
Sedang & $0,5-1,0$ \\
Besar & $1,0-3,0$ \\
Sangat besar & $>3,0$ \\
\hline
\end{tabular}

Sumber: MKJI, 1997

2. Tipe lingkungan jalan

Tipe lingkungan jalan menggambarkan tata guna lahan dan akses dari seluruh aktivitas jalan. Tipe lingkungan dapat diidentifikasi sebagaimana pada tabel berikut :

Tabel 3. Tipe Lingkungan Jalan

\begin{tabular}{|c|l|}
\hline Komersial & $\begin{array}{l}\text { Tata guna lahan komersial } \\
\text { (misalnya pertokoan, rumah } \\
\text { makan, perkantoran) dengan jalan } \\
\text { masuk langsung bagi pejalan kaki } \\
\text { dan kendaraan. }\end{array}$ \\
Pemukiman & $\begin{array}{l}\text { Tata guna lahan tempat tinggal } \\
\text { dengan jalan masuk langsung } \\
\text { bagi pejalan kaki dan kendaraan. }\end{array}$ \\
Akses terbatas & $\begin{array}{l}\text { Tanpa jalan masuk atau jalan } \\
\text { masuk langsung terbatas } \\
\text { (misalnya karena adanya } \\
\text { penghalang fisik, jalan langsung } \\
\text { dsb). }\end{array}$ \\
\hline
\end{tabular}

Sumber : MKJI, 1997

3. Kelas hambatan samping

Hambatan samping menunjukan pengaruh aktivitas samping jalan di daerah simpang pada arus lalu-lintas. Hambatan samping ditentukan secara kualitatif dengan pertimbangan teknik lalu-lintas sebagai tinggi, sedang, atau

\section{Kapasitas Simpang $(c)$}

Kapasitas adalah ukuran kinerja (performace) pada kondisi yang sangat kompleks. Kapasitas total untuk seluruh lengan simpang adalah hasil perkalian dasar (Co) yaitu kapasitas pada kondisi tertentu dan faktor- faktor penyesuaian $(F)$, dengan memperhitungkan pengaruh lapangan terhadap kapasitas. Nilai kapasitas aktual, $C$ ( smp/ jam ) dapat dihitung dengan rumus :

$\mathrm{C}=\mathrm{C}_{0} \mathrm{xF}_{\mathrm{w}} \mathrm{xF}_{\mathrm{M}} \mathrm{xF}_{\mathrm{CS}} \mathrm{xF}_{\mathrm{RSU}} \mathrm{xF}_{\mathrm{LT}} \mathrm{xF}_{\mathrm{RT}} \mathrm{xF}_{\mathrm{MI}}$

Variabel-variabel yang digunakan untuk memperhitungan yang berdasarkan Manual Kapasitas Jalan Indonesia (MKJI) adalah:

1. $\mathrm{Q}_{\mathrm{MI}}(\mathrm{smp} / \mathrm{jam})$ : Total arus pada jalan minor

2. $\mathrm{Q}_{\mathrm{MA}}(\mathrm{smp} / \mathrm{jam})$ : Total arus pada jalan utama

3. $\mathrm{Q}_{\mathrm{LT}}$ ( smp / jam) : Total arus pada jalan kiri

4. $\mathrm{Q}_{\mathrm{RT}}(\mathrm{smp} / \mathrm{jam})$ : Total arus pada jalan kanan

5. $\mathrm{Q}_{\text {TOtal }}($ smp / jam): Total arus masuk

6. $\mathrm{P}_{\mathrm{LT}} \quad$ : Rasio arus belok kiri

$\mathrm{P}_{\mathrm{LT}}=\left(\mathrm{Q}_{\mathrm{LT}} / \mathrm{Q}_{\mathrm{TOTAL}}\right)$
7. $\mathrm{P}_{\mathrm{RT}}$

Rasio arus belok kanan

$\mathrm{P}_{\mathrm{RT}}=\left(\mathrm{Q}_{\mathrm{RT}} / \mathrm{Q}_{\mathrm{TOTAL}}\right)$

8. $\mathrm{P}_{\mathrm{MI}} \quad$ : Rasio arus jalan minor $\mathrm{P}_{\mathrm{MI}}=\left(\mathrm{Q}_{\mathrm{MI}} / \mathrm{Q}_{\mathrm{TOTAL}}\right)$

9. $\mathrm{P}_{\mathrm{UM}} \quad$ : Rasio arus kendaraan tak bermotor ( kend/jam )

$\mathrm{P}_{\mathrm{UM}}=\left(\mathrm{Q}_{\mathrm{UM}} / \mathrm{Q}_{\mathrm{TOTAL}}\right)$

10. Faktor smp : Perhitungan dari nilai smp dan komposisi arus

$\mathrm{P}_{\mathrm{LT}}=\left(\mathrm{A}_{\mathrm{LT}}+\mathrm{B}_{\mathrm{LT}}+\mathrm{C}_{\mathrm{LT}}+\mathrm{D}_{\mathrm{LT}}\right) /(\mathrm{A}+\mathrm{B}+\mathrm{C}+\mathrm{D})$

$\mathrm{R}_{\mathrm{PT}}=\left(\mathrm{A}_{\mathrm{RT}}+\mathrm{B}_{\mathrm{RT}}+\mathrm{C}_{\mathrm{RT}}+\mathrm{D}_{\mathrm{RT}}\right) /(\mathrm{A}+\mathrm{B}+\mathrm{C}+\mathrm{D})$

$\mathrm{P}_{\mathrm{MI}}=(\mathrm{A}+\mathrm{C}) /(\mathrm{A}+\mathrm{B}+\mathrm{C}+\mathrm{D})$

$\mathrm{Q}_{\text {TOTAL }}=\mathrm{A}+\mathrm{B}+\mathrm{C}+\mathrm{D}$

A, B,C dan D adalah volume arus lalu-lintas (smp / jam)

\section{Kinerja Jalan Berdasarkan MKJI 1997}

Tingkat kinerja jalan adalah ukuran kuantitatif yang menerangkan kondisi operasional ${ }^{[1]}$. Nilai kuantitatif dinyatakan dalam kapasitas, derajat kejenuhan, derajat ringan, kecepatan rata-rata, waktu tempuh, tundaan dan rasio kendaraan berhenti. Ukuran Kualitatif yang menerangkan kondisi operasional dalam arus lalu lintas dan persepsi pengemudi tentang kualitas berkendaraan dinyatakan dengan tingkat pelayanan jalan.

1. Kapasitas Ruas Jalan

Kapasitas didefinisikan sebagai arus maksimum melalui suatu kondisi titik di jalan yang dapat dipertahankan per satuan jam pada kondisi tertentu. Untuk jalan dua lajur dua arah, kapasitas ditentukan untuk arus dua arah (kombinasi dua arah), tetapi untuk jalan dengan banyak lajur, arah dipisahkan per arah dan kapasitas ditentukan per lajur. Persamaan dasar untuk menentukan kapasitas adalah sebagai berikut :

$\mathrm{C}=\mathrm{C}_{0} \times \mathrm{F}_{\mathrm{cw}} \times \mathrm{FC}_{\mathrm{sp}} \times \mathrm{FC}_{\mathrm{sf}} \times \mathrm{FC}_{\mathrm{cs}}$

dimana :

$\mathrm{C}=\operatorname{Kapasitas}(\mathrm{smp} / \mathrm{jam})$

$\mathrm{C}_{0}=$ Kapasitas dasar (smp/jam)

$\mathrm{F}_{\mathrm{cw}}=$ Faktor penyesuaian akibat lebar jalur lalu lintas

$\mathrm{FC}_{\mathrm{sp}}=$ Faktor penyesuaian akibat pemisah arah

$\mathrm{FC}_{\mathrm{sf}}=$ Faktor penyesuaian akibat hambatan samping

$\mathrm{FC}_{\mathrm{c}}=$ Faktor penyesuaian untuk ukuran kota

Kapasitas dasar $\left(\mathrm{C}_{\mathrm{o}}\right)$ tergantung pada tipe jalan, jumlah lajur dan apakah jalan dipisahkan dengan pemisah fisik atau seperti dalam tabel berikut:

Tabel 4. Kapasitas dasar $\left(\mathrm{C}_{\mathrm{o}}\right)$ jalan perkotaan

\begin{tabular}{|l|c|c|}
\hline Tipe Jalan Kota & $\begin{array}{c}\text { Kapasitas Dasar } \\
\text { (smp/jam) }\end{array}$ & Keterangan \\
\hline $\begin{array}{l}\text { 4 lajur dipisah atau } \\
\text { jalan satu arah }\end{array}$ & 1650 & Per lajur \\
\hline 4 lajur tidak dipisah & 1500 & Per lajur \\
\hline 2 lajur tidak dipisah & 2900 & Kedua arah \\
\hline
\end{tabular}

Sumber: MKJI, 1997

2. Hambatan Samping 
Hambatan samping yaitu aktivitas samping jalan yang dapat menimbulkan konflik dan berpengaruh terhadap pergerakan arus lalu lintas serta menurunkan kinerja jalan. Adapun tipe kejadian hambatan samping, adalah :

a. Jumlah pejalan kaki berjalan atau menyeberang sepanjang segmen jalan.

b. Jumlah kendaraan berhenti dan parkir.

c. Jumlah kendaraan bermotor yang masuk dan keluar dari lahan samping jalan dan jalan samping.

d. Arus kendaraan lambat, yaitu arus lokal (kend/jam) sepeda, becak, delman, pedati, traktor dan sebagainya.

\section{Tingkat Pelayanan / Level Of Services (LOS)}

Perilaku lalu lintas diwakili oleh tingkat pelayanan (Level Of Service), yaitu ukuran kualitatif yang mencerminkan persepsi para pengemudi dan penumpang mengenai karakteristik kondisi operasional dalam arus lalu lintas. Tingkat pelayanan adalah kemampuan ruas jalan dan/atau persimpangan untuk menampung lalu lintas pada keadaan tertentu.

Tabel 5. Nilai Tingkat Pelayanan

\begin{tabular}{|c|c|}
\hline $\begin{array}{c}\text { Tingkat } \\
\text { Pelayanan }\end{array}$ & Karakteristik Operasi Terkait \\
\hline $\mathrm{A}$ & $\begin{array}{l}\text { - Arus bebas } \\
\text { - Kecepatan lalu lintas > } 100 \mathrm{~km} / \mathrm{jam} \\
\text { - Jarak pandang bebas untuk mendahului } \\
\text { harus selalu ada } \\
\text { - Volume lalu lintas mencapai } 20 \% \text { dari } \\
\text { kapasitas (yaitu } 400 \mathrm{smp} \text { perjam, } 2 \\
\text { arah), V/C=0,2 } \\
\text { - Sekitar } 75 \% \text { dari gerakan mendahului } \\
\text { dapat dilakukan dengan sedikit atau } \\
\text { tanpa tundaan }\end{array}$ \\
\hline B & $\begin{array}{l}\text { - Awal dari kondisi arus stabil } \\
\text { - Kecepatan lalu lintas } \geq 80 \mathrm{~km} / \mathrm{jam} \\
\text { - Jarak pandang bebas untuk mendahului } \\
\text { harus selalu ada } \\
\text { - Volume lalu lintas mencapai } 45 \% \text { dari } \\
\text { kapasitas (yaitu } 1400 \mathrm{smp} \text { perjam, } 2 \\
\text { arah) } \mathrm{V} / \mathrm{C}=0,45\end{array}$ \\
\hline
\end{tabular}

\begin{tabular}{|c|c|}
\hline $\begin{array}{c}\text { Tingkat } \\
\text { Pelayanan }\end{array}$ & Karakteristik Operasi Terkait \\
\hline $\mathrm{C}$ & $\begin{array}{l}\text { - Arus masih stabil } \\
\text { - Kecepatan lalu lintas } \geq 65 \mathrm{~km} / \mathrm{jam} \\
\text { - Jarak pandang bebas untuk mendahului } \\
\text { haus selalu ada } \\
\text { - Volume lalu lintas mencapai } 70 \% \text { dari } \\
\text { kapasitas (yaitu } 1700 \text { smp perjam, } 2 \\
\text { arah), V/C }=0,7\end{array}$ \\
\hline $\mathrm{D}$ & $\begin{array}{l}\text { - Mendekati arus tidak stabil } \\
\text { - Keepatan lalu lintas turun sampai } 60 \\
\text { km/jam } \\
\text { - Jarak pandang bebas untuk mendahului } \\
\text { harus selalu ada } \\
\text { - Volume lalu lintas mencapai } 85 \% \text { dari } \\
\text { kapasitas (yaitu } 1700 \text { smp perjam, } 2 \\
\text { arah), V/C =0,85 }\end{array}$ \\
\hline $\mathrm{E}$ & $\begin{array}{l}\text { - Kondisi mencapai kapasitas dengan } \\
\text { volume mencapai } 2000 \mathrm{smp} \text { perjam, } 2 \\
\text { arah } \\
\text { - Kecepatan lalu lintas pada umumnya } \\
\text { berkisar } 50 \mathrm{~km} / \mathrm{jam}\end{array}$ \\
\hline $\mathrm{F}$ & $\begin{array}{l}\text { - Kondisi arus tertahan } \\
\text { - Kecepatan lalu lintas }<50 \mathrm{~km} / \mathrm{jam} \\
\text { - Volume dibawah } 2000 \mathrm{smp} \text { perjam }\end{array}$ \\
\hline
\end{tabular}

\section{Peneliti Terdahulu (study desk)}

Kajian penelitian mengenai kinerja persimpangan bersinyal dan ruas jalan sudah banyak dilakukan karena konflik yang terjadi di masing daerah kajian yang berbeda-beda serta kompleksnya permasalahan yang terjadi, sehingga mendorong para ahli dibidang transportasi merasa perlu untuk melakukan penelitian dan kajian ini sebagai salah satu referensi untuk mengatasi permasalahan transportasi yang terjadi dikawasan persimpangan. Pada Tabel 6 dibawah ini terlihat beberapa penelitian yang mengangkat permasalahan kinerja simpang dan ruas jalan berikut perumusan permasalahan beserta capaian yang didapat dari kajian penelitian tersebut.

Tabel 6. Peneliti Terdahulu (study desk)

\begin{tabular}{|c|l|c|l|l|}
\hline No. & Judul Penelitian & $\begin{array}{c}\text { Nama Jurnal/ } \\
\text { vol/ tahun }\end{array}$ & Rumusan Masalah & Capaian yang dihasilkan \\
\hline 1 & $\begin{array}{l}\text { Studi Kinerja Ruas dan } \\
\text { Persimpangan Dikawasan } \\
\text { Lapangan Karebosi pada } \\
\text { Jln Jend. Sudirman Kota } \\
\text { Makassar }\end{array}$ & $\begin{array}{c}\text { Transportasi/ 06 } \\
\text { Jun 2006 }\end{array}$ & $\begin{array}{l}\text { Permasalahan } \\
\text { kemacetan dan antrian } \\
\text { yang terjadi di ruas } \\
\text { jalan dan } \\
\text { persimpangan } \\
\text { terutama pada area } \\
\text { sebelum dan atau kaki } \\
\text { simpang }\end{array}$ & $\begin{array}{l}\text { Mengetahui kinerja arus lalu lintas pada } \\
\text { ruas jalan Jend. Sudirman dan } \\
\text { menganalisis tingkat pelayanan } \\
\text { persimpangan Jln.Jend. Sudirman-Jln. } \\
\text { Bawakaraeng-Jln. R.A. Kartini Kota } \\
\text { Makassar }\end{array}$ \\
\hline 2 & $\begin{array}{l}\text { Kontribusi Mobilitas } \\
\text { Siswa SMAN Favorit } \\
\text { terhadap Kinerja Ruas } \\
\text { Jalan di Kota Bandung }\end{array}$ & $\begin{array}{c}\text { Transportasi/ 11 } \\
\text { Des 2011 }\end{array}$ & $\begin{array}{l}\text { Pengaruh mobilitas } \\
\text { siswa terhadap tingkat } \\
\text { pelayanan ruas jalan }\end{array}$ & $\begin{array}{l}\text { - Mengetahui jumlah siswa yang } \\
\text { melakukan mobilitas dari pemukiman } \\
\text { ke pusat kota Bandung } \\
\text { Menentukan kontribusi mobilitas } \\
\text { siswa terhadap kinerja ruas jalan }\end{array}$ \\
\hline
\end{tabular}




\begin{tabular}{|c|l|c|l|l|}
\hline No. & Judul Penelitian & $\begin{array}{c}\text { Nama Jurnal/ } \\
\text { vol/tahun }\end{array}$ & Rumusan Masalah & Capaian yang dihasilkan \\
\hline 3 & $\begin{array}{l}\text { Pengukuran Tingkat } \\
\text { Kinerja Ruas Jalan } \\
\text { Menggunakan Data GPS }\end{array}$ & $\begin{array}{c}\text { Transportasi/ 13 } \\
\text { April 2013 }\end{array}$ & $\begin{array}{l}\text { Mengukur kinerja } \\
\text { ruas jalan dengan } \\
\text { menggunakan data } \\
\text { informasi kecapatan } \\
\text { lalu lintas RTTIS }\end{array}$ & $\begin{array}{l}\text { - Memperoleh kecepatan lalu lintas } \\
\text { rata-rata dari kendaraan uji yang } \\
\text { telah dipasang GPS } \\
\text { - Mengetahui kinerja ruas jalan dengan } \\
\text { melihat kecepatan rata-rata } \\
\text { kendaraan }\end{array}$ \\
\hline
\end{tabular}

Sumber: Hasil pengumpulan data

\section{Metodologi Penelitian}

Metodologi yang digunakan pada analisis pada simpang Angkatan 66 dan ruas jalan R. Soekamto, dijelaskan sebagai berikut:

\section{Observasi Lapangan}

Observasi lapangan dilakukan dalam beberapa tahapan, sehingga memungkinkan dalam pengambilan data. Untuk itu pada observasi lapangan ini meliputi waktu ataupun tempat survei dan karakteristik kelas jalan yang dijelaskan sebagai berikut :

1. Waktu dan Tempat Survei

a. Waktu Survei

Sebelum melakukan survei volume lalulintas, dilakukan survei pendahuluan untuk menentukan waktu dan hari tersibuk dalam satu minggu yaitu dengan melakukan observasi pada simpang dan ruas jalan dari hari senin sampai dengan hari minggu pada masing-masing kaki simpang dan ruas jalan. Waktu Penelitian dilakukan dengan perincian sebagai berikut : Untuk survey persimpangan pengambilan data volume lalu-lintas dihitung setiap 15 menit selama 3 jam pagi, 15 menit selama 3 jam siang, 15 menit selama 3,5 jam sore. Dimulai dari jam 06:00-09:00, 11:0014:00, 15:00-18:00. Sama halnya dengan survei yang dilakukan pada persimpangan, hanya untuk survei ruas jalan dilakukan mulai pukul 06:00-18:00 dihitung setiap 15 menit tanpa jedah waktu.

b. Tempat Survei

Tempat atau Lokasi survei dilakukan pada masing-masing kaki simpang Jl. Angkatan 66 dan penggalan ruas jalan R. Soekamto kota Palembang.

2. Tenaga Survei

Dalam penelitian ini diperlukan 14 (empat belas) orang surveyor yang bertugas:

a. Survei volume arus lalu-lintas

b. Survei geometrik jalan

3. Peralatan

Peralatan yang dipakai dalam penelitian ini adalah:

a. Jam tangan, untuk mencatat waktu

b. Alat tulis, untuk memudahkan pengambilan data

c. Formulir survei, untuk memudahkan pengambilan data d. Roolmeter, untuk pengukuran lebar jalan, trotoar dan median jalan.

e. Kamera digital, untuk mendokumentasikan selama kegiatan berlangsung.

f. Handycam, untuk merekam pergerakan arus lalu lintas selama survey.

\section{Pengumpulan Data}

Pengumpulan data terbagi dalam pengambilan data primer dan pengambilan data sekunder.

1. Data Primer

Data primer merupakan pengambilan data yang diambil dari hasil survei langsung dilokasi penelitian, data yang diambil yaitu data geometrik simpang, data kondisi lalu-lintas dan data kondisi lingkungan simpang

a. Data geometrik simpang

Data geometrik simpang diperoleh dari pengukuran yang meliputi pengukuran lebar jalan, lebar trotoar, lebar median dan saluran drainase.

b. Kondisi lalu-lintas

Kondisi lalu-lintas adalah jumlah kendaraan yang melintas pada simpang tersebut persatuan waktu.

\section{Data Sekunder}

Data sekunder merupakan data penunjang diperoleh dari kerjasama antara instansi yang terkait. Data yang dibutuhkan adalah data jumlah penduduk dan data luas daerah.

\section{Analisa}

Analisa perhitungan dalam bentuk perhitungan manual dengan menggunakan rumus yang terdapat dalam buku Manual Kapasitas Jalan Indonesia (MKJI), analisa tersebut untuk menghitung kapasitas simpang dan tingkat layanan.

1. Data masukan

Data yang diperlukan untuk mempermudah perhitungan simpang bersinyal adalah:

a. Kondisi geometrik simpang.

Data kondisi geometrik simpang, merupakan data yang menginformasikan tentang kerb, lebar jalur, bahu, median, dan saluran drainase. Selain itu juga data ini dapat menggambarkan tentang jalan utama dan jalan minor pada geometrik simpang tersebut

b. Kondisi lalu-lintas

Data ini merupakan data arus lalu-lintas pada saat jam sibuk, data ini diketahui berdasarkan perhitungan volume kendaraan yang melintas 
pada kaki simpang menurut arus jam rencana atau lalu-lintas Harian Rata-Rata

c. Data Kondisi Lingkungan

Data lingkungan yang diperlukan untuk perhitungan meliputi data sebagai berikut :

- Kelas Ukuran Kota.

- Tipe Lingkungan Jalan

- Kelas Hambatan Samping

2. Kapasitas

Dari data masukan yang didapat kemudian dilakukan perhitungan kapasitas untuk masingmasing kaki simpang dengan rumus MKJI.

3. Rasio Tingkat Layanan

Dari data olahan hasil survei arus kendaraan dan perhitungan kapasitas simpang, maka selanjutnya dapat diperoleh rasio tingkat pelayanan sesuai dengan Tabel Tingkat Pelayanan Simpang.

\section{Analisa dan Pembahasan}

\section{Data Hasil Penelitian}

Hasil pengumpulan data persimpangan diperoleh dari survei lapangan pada masing-masing kaki simpang pada persimpangan Jl. Angkatan 66 - Jl. Basuki Rahmat yang dilakukan pada hari senin tanggal 17 Juli 2017 sedangkan untuk ruas jalan R. Soekamto dilakukan pada hari senin tanggal 24 Juli 2017. Data diambil pada jam puncak (peak hour faktor) dimana kondisi jam puncak tersebut diambil berdasarkan hasil observasi pengamatan selama satu minggu. Untuk melihat kondisi existing persimpangan dengan secara lebih jelas diperlihatkan pada peta lokasi persimpangan dan sketsa kondisi geometrik persimpangan (lebar jalan, trotoar, median dan bahu jalan) serta foto lapangan persimpangan Jl. Angkatan 66 - Jl. Basuki Rahmat Kota Palembang yang dapat dilihat pada Gambar 1 dan Gambar 2 berikut :

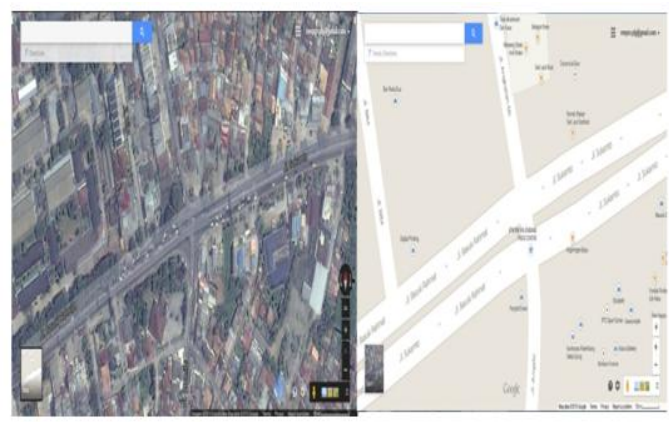

Gambar 1. Lokasi Pada Persimpangan Jl. Angkatan 66 Jl. Basuki Rahmat (Sumber: Google Maps, 2017)

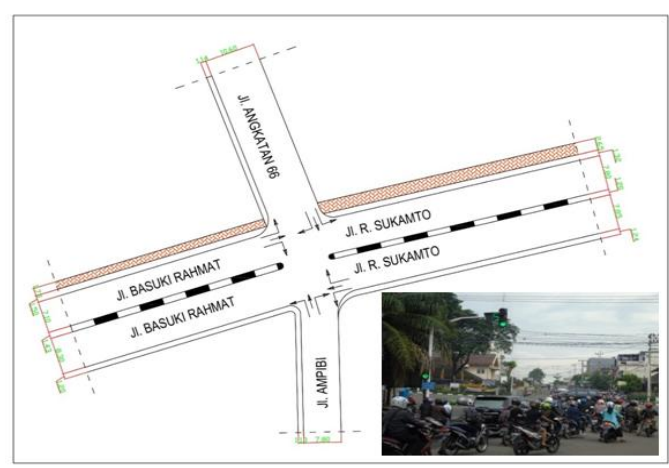

Gambar 2. Sketsa Kondisi Geometrik Persimpangan (Sumber: Pengolahan Data, 2017)

\section{Data Geometrik Simpang}

Pengambilan data geometrik simpang ditunjukkan pada tabel 7 berikut ini :

Tabel 7. Data Geometrik Persimpangan Angkatan 66

\begin{tabular}{|c|c|c|c|c|c|c|c|c|}
\hline \multirow{3}{*}{$\begin{array}{c}\text { Data Geometrik } \\
\text { Bahu Jalan }\end{array}$} & \multicolumn{8}{|c|}{ Simpang Jl. Angkatan 66 - Jl. Basuki Rahmat } \\
\hline & \multicolumn{2}{|c|}{ Basuki Rahmat } & \multicolumn{2}{|c|}{ Angkatan 66} & \multicolumn{2}{|c|}{ R. Sukamto } & \multicolumn{2}{|c|}{ Ampibi } \\
\hline & 1,5 & 1,2 & 1,14 & - & 1,32 & 1,24 & - & 1,13 \\
\hline Trotoar & 1,73 & & \multicolumn{2}{|c|}{-} & 2,65 & - & - & - \\
\hline Median & \multicolumn{2}{|c|}{1,43} & \multicolumn{2}{|c|}{-} & \multicolumn{2}{|c|}{1,2} & - & \\
\hline Lebar Jalan & 7,1 & 8,3 & \multicolumn{2}{|c|}{10,6} & 7,8 & 7,85 & \multicolumn{2}{|c|}{7,8} \\
\hline
\end{tabular}

Sumber : Pengolahan Data, 2017

\section{Data Arus Lalu-lintas Simpang}

Data jumlah kendaraan yang melintas dari masing-masing kaki simpang berupa kendaraan yang belok kiri, lurus, maupun belok kanan dengan membedakan jenis kendaraan berupa kendaraan berat (Heavy Vehicle / HV), kendaraan ringan (Light Vehicle LV), Sepeda Motor (Motor Cycle/MC), dan Kendaraan tak bermotor (UnMotorized/UM). Data tersebut secara terperinci dapat terlihat pada gambar 3 berikut: 

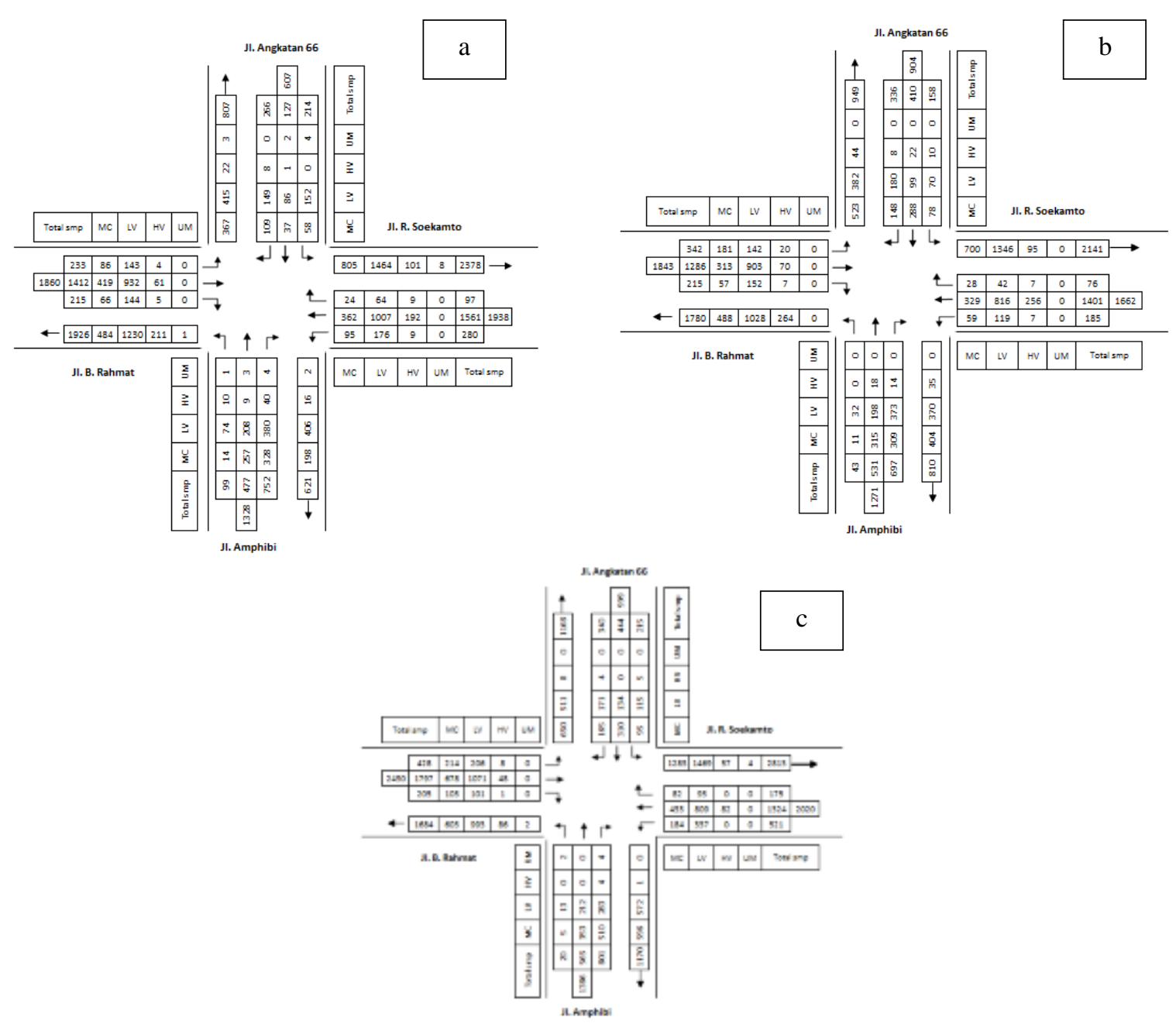

Gambar 3. Denah dan Volume Lalu-lintas di Persimpangan Angkatan 66 pada Kondisi Puncak (a) Kondisi Puncak Pagi; (b) Kondisi Puncak Siang; (c) Kondisi Puncak Sore

Sumber : Pengolahan Data, 2017

\section{Kondisi Lingkungan Simpang}

Data kondisi lingkungaan simpang digunakan untuk menentukan rasio kendaraan tak bermotor dan hambatan samping. Dari pengamatan diketahui bahwa simpang Angkatan 66 berada di lingkungan komersial ditandai dengan berdirinya toko-toko, perkantoran-perkantoran dan usaha komersial lainnya dengan kelas hambatan samping sedang.

\section{Analisa Perhitungan Kapasitas Simpang}

Dari data primer (data geometrik, data arus lalulintas, data kondisi lingkungan) serta data sekunder (data ukuran kota/ jumlah penduduk) dapat dilakukan analisa perhitungan kapasitas simpang. Angkatan 66 hasilnya dapat dilihat berdasarkan tabel dibawah ini

Tabel 8. Kapasitas Simpang Angkatan 66

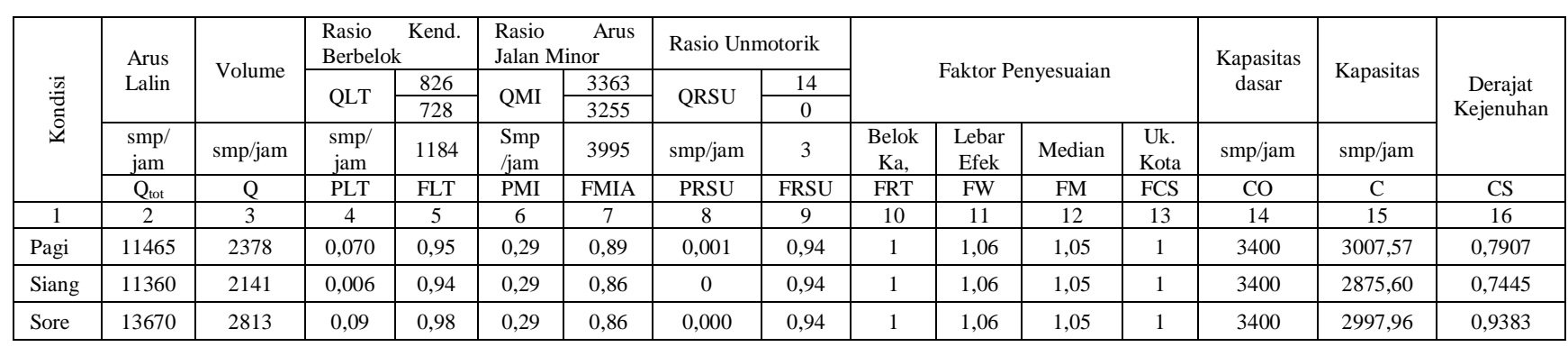

Sumber: Pengolahan Data, 2017 


\section{Analisa Perhitungan Kinerja Simpang}

Analisa kinerja persimpangan dan kaki simpang, dilakukan pada persimpangan Jl. Angkatan 66 - Jl. Basuki Rahmat Kota Palembang. Dari data volume lalu-lintas pada masing-masing kaki simpang dan perhitungan kapasitas simpang dapat dihitung rasio 1. Pada kondisi puncak pagi
V/C yang kemudian diklasifikasikan tingkat pelayanan kinerja persimpangan. Hasil analisa perhitungan dan pembahasan dapat diuraikan sebagai berikut:

Tabel 9. Kinerja Kaki Simpang Jl. Angkatan 66 - Jl. Basuki Rahmat

\begin{tabular}{|c|c|c|c|c|c|c|}
\hline No. & Jalan & Arah & Volume (V) & Kapasitas (C) & V/C & LOS \\
\hline 1 & Jln. Basuki Rahmat & Simpang Polda & 1926 & 3007 & 0,6405 & C \\
\hline 2 & Jln. Basuki Rahmat & Jln. R. Sukamto & 1860 & 3007 & 0,6186 & C \\
\hline 3 & Jln. Ampibi & - & 1949 & 3007 & 0,6482 & C \\
\hline 4 & Jln. R. Sukamto & PTC & 2387 & 3007 & 0,7908 & C \\
\hline 5 & Jln. R. Sukamto & Jln. Basuki Rahmat & 1414 & 3007 & 0,6445 & C \\
\hline
\end{tabular}

Ket: $\mathrm{A} \leq 0,40 ; \mathrm{B} \leq 0,58 ; \mathrm{C} \leq 0,80 ; \mathrm{D} \leq 0,90 ; \mathrm{E} \leq 1,0 ; \mathrm{F}>1$

Sumber: Manual Kapasitas Jalan Indonesia (MKJI, 1997)

2. Pada kondisi puncak siang

Tabel 10. Kinerja Kaki Simpang Jl. Angkatan 66 - Jl. Basuki Rahmat

\begin{tabular}{|c|c|c|c|c|c|c|}
\hline No. & Jalan & Arah & Volume (V) & Kapasitas (C) & V/C & LOS \\
\hline 1 & Jln. Basuki Rahmat & Simpang Polda & 1780 & 2875 & 0,6191 & C \\
\hline 2 & Jln. Basuki Rahmat & Jln. R. Sukamto & 1843 & 2875 & 0,6410 & C \\
\hline 3 & Jln. Ampibi & - & 2081 & 2875 & 0,7238 & C \\
\hline 4 & Jln. R. Sukamto & PTC & 2141 & 2875 & 0,7447 & C \\
\hline 5 & Jln. R. Sukamto & Jln. Basuki Rahmat & 1662 & 2875 & 0,5781 & C \\
\hline 6 & Jln. Angkatan 66 & - & 1853 & 2875 & 0,6446 & $\mathrm{C}$ \\
\hline
\end{tabular}

Ket: $\mathrm{A} \leq 0,40 ; \mathrm{B} \leq 0,58 ; \mathrm{C} \leq 0,80 ; \mathrm{D} \leq 0,90 ; \mathrm{E} \leq 1,0 ; \mathrm{F}>1$

Sumber: Manual Kapasitas Jalan Indonesia (MKJI, 1997)

3. Pada kondisi puncak Sore

Tabel 11. Kinerja Kaki Simpang Jl. Angkatan 66

\begin{tabular}{|c|c|c|c|c|c|c|}
\hline No. & Jalan & Arah & Volume (V) & Kapasitas (C) & V/C & LOS \\
\hline 1 & Jln. Basuki Rahmat & Simpang Polda & 1684 & 2997 & 0,5619 & B \\
\hline 2 & Jln. Basuki Rahmat & Jln. R. Sukamto & 2430 & 2997 & 0,8108 & D \\
\hline 3 & Jln. Ampibi & - & 2556 & 2997 & 0,8529 & D \\
\hline 4 & Jln. R. Sukamto & PTC & 2813 & 2997 & 0,9386 & D \\
\hline 5 & Jln. R. Sukamto & Jln. Basuki Rahmat & 2020 & 2997 & 0,6740 & C \\
\hline 6 & Jln. Angkatan 66 & - & 2167 & 2997 & 0,7231 & C \\
\hline
\end{tabular}

Ket: $\mathrm{A} \leq 0,40 ; \mathrm{B} \leq 0,58 ; \mathrm{C} \leq 0,80 ; \mathrm{D} \leq 0,90 ; \mathrm{E} \leq 1,0 ; \mathrm{F}>1$

Sumber: Manual Kapasitas Jalan Indonesia (MKJI, 1997)
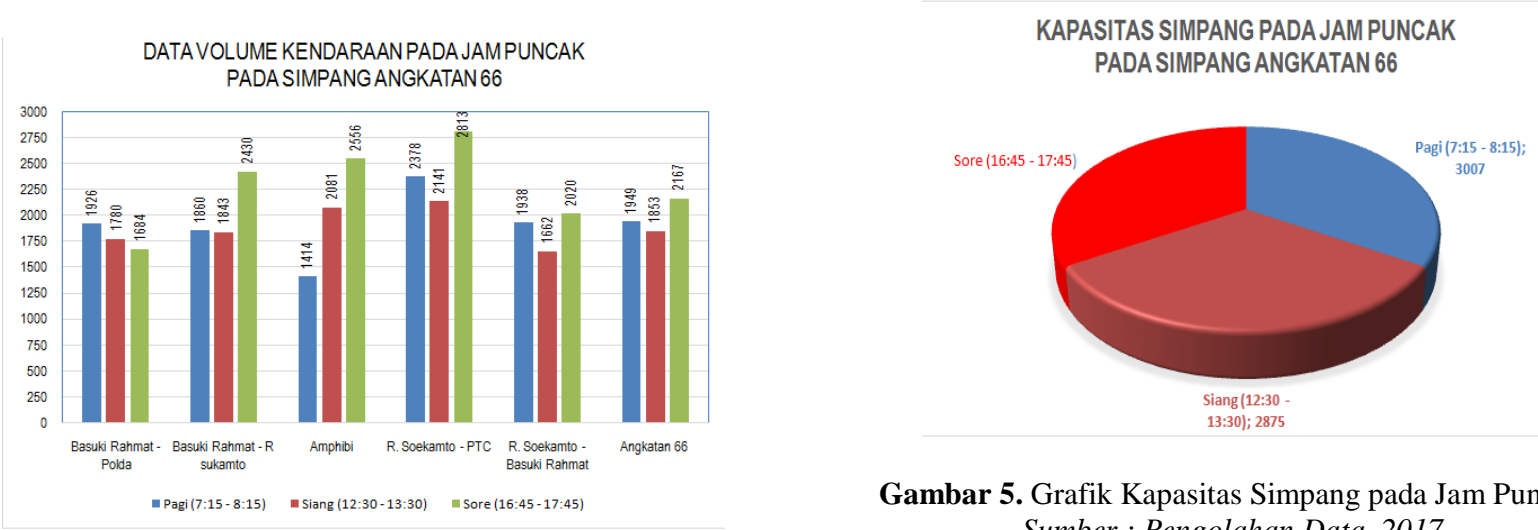

Gambar 5. Grafik Kapasitas Simpang pada Jam Puncak Sumber : Pengolahan Data, 2017

Gambar 4. Grafik Volume Kendaraan pada Jam Puncak Sumber : Pengolahan Data, 2017 


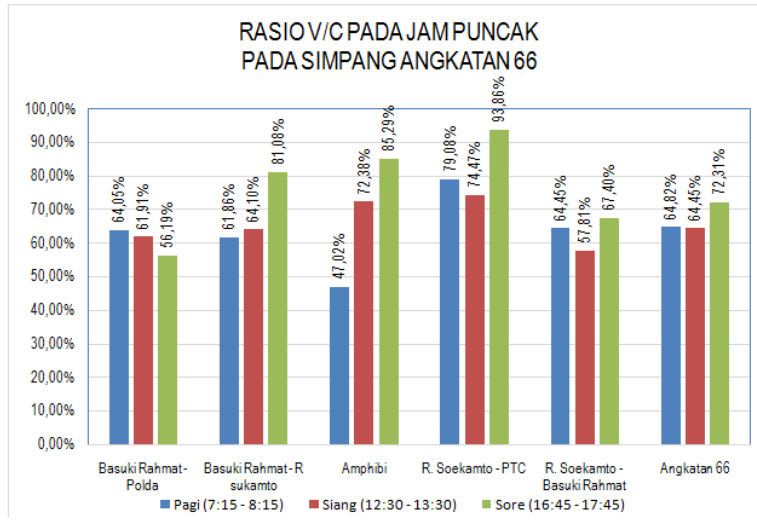

Gambar 6. Grafik Rasio V/C pada Jam Puncak Sumber : Pengolahan Data, 2017

\section{Analisa Perhitungan Kinerja dan Kapasitas Ruas Jalan}

1. Kinerja dan Kapasitas Jalan R. Soekamto Arah Angkatan 66

a. Kondisi Arus Lalu Lintas J1. R. Soekamto

Tabel 12. Kondisi Arus Lalu Lintas Jalan R. Soekamto Arah Angkatan 66

\begin{tabular}{|c|c|c|c|c|c|}
\hline \multirow{2}{*}{ Periode Waktu } & \multicolumn{4}{|c|}{ Jenis Kendaraan } & \multirow{2}{*}{$\begin{array}{c}\text { Volume } \\
\text { (smp/jam) }\end{array}$} \\
\hline & MC & LV & $\mathrm{HV}$ & UM & \\
\hline $06: 00-07: 00$ & 426 & 1106,4 & 212 & 0 & 1744 \\
\hline 07:00 - 08:00 & 561 & 1358,4 & 207 & 0 & 2127 \\
\hline 08:00 - 09:00 & 464 & 1285,2 & 175 & 0 & 1924 \\
\hline 09:00 - 10:00 & 476 & 1194 & 78 & 0 & 1748 \\
\hline $10: 00-11: 00$ & 463 & 1160,4 & 173 & 0 & 1796 \\
\hline $11: 00-12: 00$ & 394 & 1107,6 & 269 & 0 & 1771 \\
\hline $12: 00-13: 00$ & 481 & 1054,8 & 267 & 0 & 1803 \\
\hline $13: 00-14: 00$ & 455 & 1033,2 & 137 & 0 & 1626 \\
\hline $14: 00-15: 00$ & 386 & 894 & 133 & 0 & 1413 \\
\hline $15: 00-16: 00$ & 559 & 1124,4 & 84 & 0 & 1767 \\
\hline $16: 00-17: 00$ & 510 & 1226,4 & 108 & 0 & 1840 \\
\hline $17: 00-18: 00$ & 760 & 1418,4 & 111 & 0 & 2289 \\
\hline
\end{tabular}

Sumber: Pengolahan Data, 2017

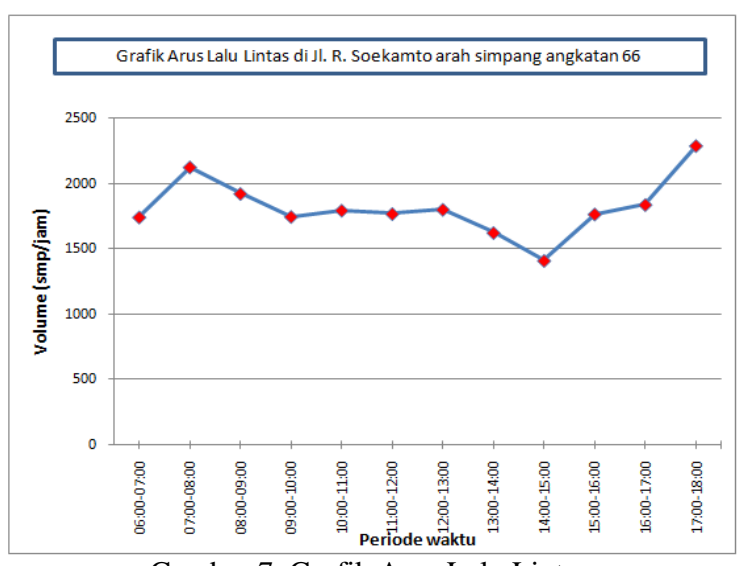

Gambar 7. Grafik Arus Lalu Lintas Sumber : Pengolahan Data, 2017 b. Penggunaan Moda

Tabel 13. Penggunaan moda Jl.R.Seokamto

\begin{tabular}{|c|l|c|c|}
\hline No. & \multicolumn{1}{|c|}{ Kendaraan } & Jumlah & Persentase \\
\hline 1 & Sepeda motor & 14838 & 49,0 \\
\hline 2 & Mobil pribadi & 11988 & 39,5 \\
\hline 3 & Angkutan umum & 1165,2 & 3,8 \\
\hline 4 & Pick up & 810 & 2,7 \\
\hline 5 & Bus pendek & 132,4 & 0,4 \\
\hline 6 & Bus panjang & 184,8 & 0,6 \\
\hline 7 & Trul engkel & 781,2 & 2,6 \\
\hline 8 & Truk fuso & 266,4 & 0,9 \\
\hline 9 & Truk tronton & 134,4 & 0,4 \\
\hline 10 & Sepeda & 12 & 0,0 \\
\hline 11 & Becak & 0 & 0,0 \\
\hline & Total & 30312,4 & 100 \\
\hline
\end{tabular}

Sumber : Pengolahan data, 2017 


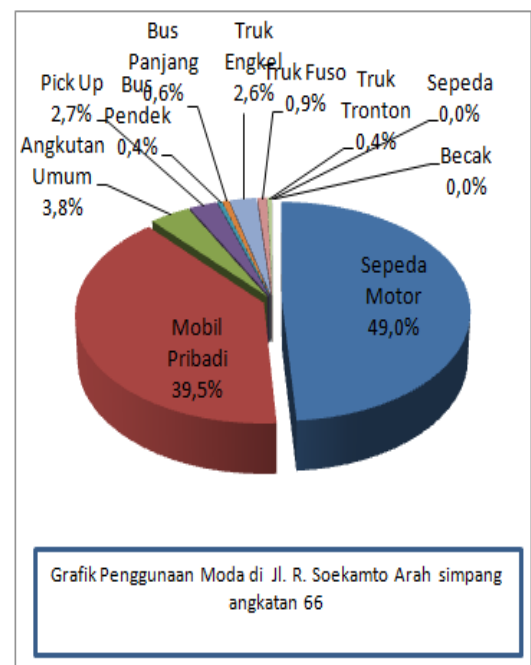

Gambar 8. Grafik Penggunaan Moda Sumber : Pengolahan Data, 2017
Rumus kapasitas jalan:

$\mathrm{C}=\mathrm{C}_{0} \times \mathrm{F}_{\mathrm{cw}} \times \mathrm{FC}_{\mathrm{sp}} \times \mathrm{FC}_{\mathrm{sf}} \times \mathrm{FC}_{\mathrm{cs}}$

$\mathrm{C}=\operatorname{Kapasitas}(\mathrm{smp} / \mathrm{jam})$

$\mathrm{C}_{0}=$ Kapasitas dasar (smp/jam)

$\mathrm{F}_{\mathrm{cw}}=$ Faktor penyesuaian akibat lebar jalur lalu lintas

$\mathrm{FC}_{\mathrm{sp}}=$ Faktor penyesuaian akibat pemisah arah

$\mathrm{FC}_{\mathrm{sf}}=$ Faktor penyesuaian akibat hambatan samping

$\mathrm{FC}_{\mathrm{c}}=$ Faktor penyesuaian untuk ukuran kota

Kondisi Jalan

Jenis Jalan $=4 / 2 \mathrm{D}$ maka $\mathrm{C}_{\mathrm{o}}=3300$

Lebar Lajur $\quad=\quad 3,9$ maka $\mathrm{FC}_{\mathrm{W}}=1,04$

Pemisahan arah $=-$ maka $\mathrm{FC}_{\mathrm{sp}}=1$

Hamb samping $=\mathrm{L}$ maka $\mathrm{FC}_{\mathrm{sf}}=0,94$

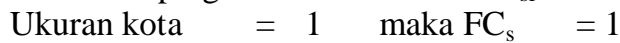

Volume pagi $=2127 \mathrm{smp} / \mathrm{jam}$

Volume siang $=1803 \mathrm{smp} / \mathrm{jam}$

Volume sore $=2289 \mathrm{smp} / \mathrm{jam}$

c. Analisa Kinerja dan Kapasitas Ruas Jalan R.

Soekamto

Tabel 14. Perhitungan Kinerja dan Kapasitas Ruas Jalan R. Soekamto Arah Angkatan 66

\begin{tabular}{|c|c|c|c|c|c|c|c|c|c|}
\hline \multirow{3}{*}{ Waktu } & \multirow{3}{*}{$\begin{array}{c}\begin{array}{c}\text { Kapasitas } \\
\text { Dasar } \\
\left(\mathrm{C}_{\mathrm{o}}\right)\end{array} \\
\text { smp/jam }\end{array}$} & \multicolumn{4}{|c|}{ Faktor Penyesuaian } & \multirow{3}{*}{$\begin{array}{c}\text { Volume } \\
\mathrm{Q} \\
\text { smp/jam }\end{array}$} & \multirow{3}{*}{$\begin{array}{c}\text { Kapasitas } \\
\mathrm{C} \\
\text { smp/jam }\end{array}$} & \multirow{3}{*}{$\mathrm{V} / \mathrm{C}$} & \multirow{3}{*}{ LOS } \\
\hline & & \multirow{2}{*}{$\begin{array}{c}\text { Lebar jalur } \\
\mathrm{F}_{\mathrm{cw}}\end{array}$} & \multirow{2}{*}{$\begin{array}{c}\text { Pemisah } \\
\text { arah } \\
\mathrm{FC}_{\mathrm{sp}} \\
\end{array}$} & \multirow{2}{*}{$\begin{array}{c}\text { Hambatan } \\
\text { samping } \\
\text { FC }_{\text {sf }} \\
\end{array}$} & \multirow{2}{*}{$\begin{array}{c}\text { Ukuran } \\
\text { kota } \\
\text { FC }_{\mathrm{c}}\end{array}$} & & & & \\
\hline & & & & & & & & & \\
\hline 1 & 2 & 3 & 4 & 5 & 6 & 7 & 8 & 9 & 10 \\
\hline Pagi & 3300 & 1,04 & 1 & 0,94 & 1 & 2127 & 3226 & 0,659 & $\mathrm{C}$ \\
\hline Siang & 3300 & 1,04 & 1 & 0,94 & 1 & 1803 & 3226 & 0,559 & $\mathrm{C}$ \\
\hline Sore & 3300 & 1,04 & 1 & 0,94 & 1 & 2289 & 3226 & 0,710 & D \\
\hline
\end{tabular}

Sumber : Pengolahan Data, 2017

\section{Jalan R. Soekamto Arah PTC Mall}

a. Kondisi Arus Lalu Lintas Jl. R. Soekamto

Tabel 15. Kondisi Arus Lalu Lintas Jalan R Soekamto arah PTC Mall

\begin{tabular}{|c|c|c|c|c|c|}
\hline \multirow{2}{*}{ Periode Waktu } & \multicolumn{4}{|c|}{ Jenis Kendaraan } & \multirow{2}{*}{$\begin{array}{c}\text { Volume } \\
\text { (smp/jam) }\end{array}$} \\
\hline & $\mathrm{MC}$ & $\mathrm{LV}$ & $\mathrm{HV}$ & UM & \\
\hline 06:00-07:00 & 692 & 1272 & 95 & 0 & 2059 \\
\hline 07:00-08:00 & 816 & 1795,2 & 139 & 0 & 2750 \\
\hline 08:00-09:00 & 843 & 1642,8 & 164 & 0 & 2650 \\
\hline 09:00 - 10:00 & 764 & 1628,4 & 158 & 0 & 2550 \\
\hline $10: 00-11: 00$ & 666 & 1155,6 & 129 & 0 & 1951 \\
\hline $11: 00-12: 00$ & 661 & 1298,4 & 149 & 0 & 2109 \\
\hline $12: 00-13: 00$ & 504 & 1212,6 & 142 & 0 & 1859 \\
\hline $13: 00-14: 00$ & 756 & 1193,8 & 136 & 0 & 2086 \\
\hline $14: 00-15: 00$ & 659 & 1272 & 108 & 0 & 2038 \\
\hline $15: 00-16: 00$ & 919 & 1386,4 & 118 & 0 & 2423 \\
\hline $16: 00-17: 00$ & 1112 & 1455,4 & 101 & 0 & 2669 \\
\hline $17: 00-18: 00$ & 1247 & 1575,2 & 46 & 0 & 2867 \\
\hline
\end{tabular}

Sumber : Pgolahan Data, 2017 


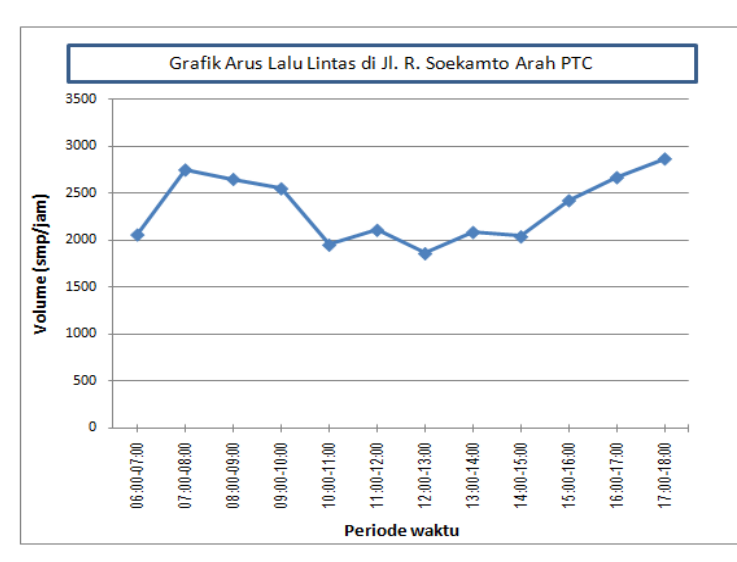

Gambar 9. Grafik Arus Lalu Lintas Sumber : Pengolahan Data, 2017

b. Penggunaan Moda

Tabel 16. Penggunaan moda Jl. R.Soekamto

\begin{tabular}{|c|c|c|c|}
\hline No. & Kendaraan & Jumlah & Persentase \\
\hline 1 & Sepeda motor & 24541,2 & 57,6 \\
\hline 2 & Mobil pribadi & 14527,2 & 34,1 \\
\hline 3 & Angkutan umum & 1597,2 & 3,8 \\
\hline 4 & Pick up & 763,4 & 1,8 \\
\hline 5 & Bus pendek & 232,8 & 0,5 \\
\hline 6 & Bus panjang & 84,8 & 0,2 \\
\hline 7 & Trul engkel & 650,2 & 1,5 \\
\hline 8 & Truk fuso & 111,4 & 0,3 \\
\hline 9 & Truk tronton & 62,4 & 0,1 \\
\hline 10 & Sepeda & 17,4 & 0,0 \\
\hline 11 & Becak & 0 & 0,0 \\
\hline \multicolumn{2}{|r|}{ Total } & 42587,6 & 100 \\
\hline
\end{tabular}

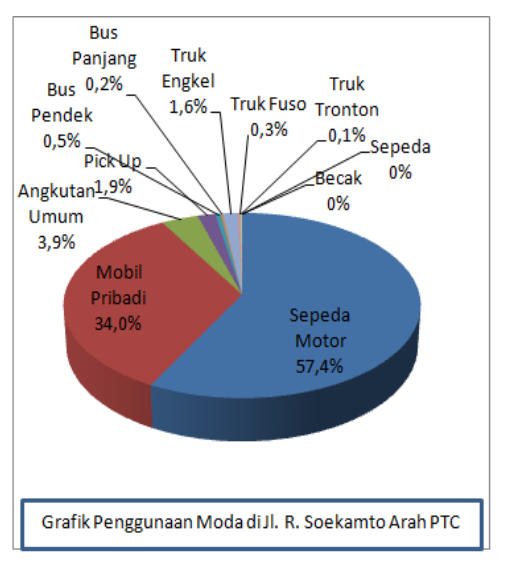

Gambar 4.10 Grafik Penggunaan Moda Sumber : Pengolahan Data, 2017

c. Analisa Kinerja dan Kapasitas Ruas Jalan R. Soekamto

Rumus kapasitas jalan:

$\mathrm{C}=\mathrm{C}_{0} \times \mathrm{F}_{\mathrm{cw}} \times \mathrm{FC}_{\mathrm{sp}} \times \mathrm{FC}_{\mathrm{sf}} \times \mathrm{FC}_{\mathrm{cs}}$

Dimana:

$\mathrm{C}=\operatorname{Kapasitas}(\mathrm{smp} / \mathrm{jam})$

$\mathrm{C}_{0}=$ Kapasitas dasar (smp/jam)

$\mathrm{F}_{\mathrm{cw}}=$ Faktor penyesuaian akibat lebar jalur lalu lintas

$\mathrm{FC}_{\mathrm{sp}}=$ Faktor penyesuaian akibat pemisah arah

$\mathrm{FC}_{\text {sf }}=$ Faktor penyesuaian akibat hambatan samping

$\mathrm{FC}_{\mathrm{c}}=$ Faktor penyesuaian untuk ukuran kota

Kondisi Jalan

Jenis Jalan $\quad=4 / 2 \mathrm{D}$ maka $\mathrm{C}_{\mathrm{o}}=3300$

Lebar Lajur $\quad=3,9$ maka $\mathrm{FC}_{\mathrm{W}}=1,04$

Pemisahan arah $=-$ maka $\mathrm{FC}_{\mathrm{sp}}=1$

Hamb samping $=\mathrm{L}$ maka $\mathrm{FC}_{\mathrm{sf}}=0,94$

Ukuran kota $=1 \quad{\text { maka } \mathrm{FC}_{\mathrm{s}}}_{\mathrm{s}}=1$

Volume pagi $=2750 \mathrm{smp} / \mathrm{jam}$

Volume siang $=2109 \mathrm{smp} / \mathrm{jam}$

Volume sore $=2867 \mathrm{smp} / \mathrm{jam}$

Tabel 17. Perhitungan Kinerja dan Kapasitas Ruas Jalan R. Soekamto Arah PTC Mall

\begin{tabular}{|c|c|c|c|c|c|c|c|c|c|}
\hline \multirow{3}{*}{ Waktu } & \multirow{3}{*}{$\begin{array}{c}\begin{array}{c}\text { Kapasitas } \\
\text { Dasar } \\
\left(\mathrm{C}_{\mathrm{o}}\right)\end{array} \\
\text { smp/jam }\end{array}$} & \multicolumn{4}{|c|}{ Faktor Penyesuaian } & \multirow{3}{*}{$\begin{array}{c}\text { Volume } \\
\mathrm{Q} \\
\text { smp/jam }\end{array}$} & \multirow{3}{*}{$\begin{array}{c}\text { Kapasitas } \\
\text { C } \\
\text { smp/jam }\end{array}$} & \multirow{3}{*}{$\mathrm{V} / \mathrm{C}$} & \multirow{3}{*}{ LOS } \\
\hline & & \multirow{2}{*}{$\begin{array}{l}\text { Lebar jalur } \\
\qquad \mathrm{F}_{\mathrm{cw}}\end{array}$} & \multirow{2}{*}{$\begin{array}{c}\text { Pemisah } \\
\text { arah } \\
\mathrm{FC}_{\mathrm{sp}}\end{array}$} & \multirow{2}{*}{$\begin{array}{c}\text { Hambatan } \\
\text { samping } \\
\mathrm{FC}_{\mathrm{sf}}\end{array}$} & \multirow{2}{*}{$\begin{array}{c}\text { Ukuran } \\
\text { kota } \\
\text { FC }_{\mathrm{c}}\end{array}$} & & & & \\
\hline & & & & & & & & & \\
\hline 1 & 2 & 3 & 4 & 5 & 6 & 7 & 8 & 9 & 10 \\
\hline Pagi & 3300 & 1,04 & 1 & 0,94 & 1 & 2750 & 3226 & 0,852 & D \\
\hline Siang & 3300 & 1,04 & 1 & 0,94 & 1 & 2109 & 3226 & 0,654 & $\mathrm{C}$ \\
\hline Sore & 3300 & 1,04 & 1 & 0,94 & 1 & 2867 & 3226 & 0,889 & $\mathrm{D}$ \\
\hline
\end{tabular}

Sumber : pengolahan data, 2017

\section{Kesimpulan}

1. Berdasarkan pada hasil perhitungan analisis survei lapangan yang telah dilakukan dengan menggunakan metode manual kapasitas jalan Indonesia (MKJI), kapasitas simpang Jl. Angkatan 66 - Jl. Basuki Rahmat Kota
Palembang pada kondisi puncak pagi adalah $3007 \mathrm{smp} / \mathrm{jam}$, pada kondisi puncak siang adalah $2875 \mathrm{smp} / \mathrm{jam}$ dan pada kondisi puncak sore adalah $2997 \mathrm{smp} / \mathrm{jam}$.

2. Tingkat pelayanan atau kinerja (Level of Service /LOS) pada persimpangan Jl. Angkatan 66 - Jl. Basuki Rahmat pada jam puncak pagi dan siang 
dengan tingkat pelayanan $\mathrm{C}$ sedangkan pada jam puncak sore dengan tingkat pelayanan $\mathrm{D}$

3. Kinerja dan kapasitas ruas jalan R. Soekamto pada ketiga waktu kondisi puncak untuk kedua arah dengan tingkat pelayanan D Arus mulai tidak stabil mulai dirasakan gangguan dalam aliran, kecepatan operasi menurun relative cepat akibat hambatan yang timbul.

4. Penggunaan moda transportasi pada ruas jalan R. Soekamto untuk kedua arah didominasi oleh kendaraan pribadi dengan persentasi nilai $80 \%$ 95\% dimana hampir $60 \%$ didominasi oleh sepeda motor, sedangkan sisanya di penuhi oleh moda transportasi lainnya.

\section{Ucapan Terima Kasih}

Penelitian ini dibiaya oleh Direktorat Riset dan

Pengabdian Masyarakat Direktorat Jenderal Penguatan Riset dan Pengembangan Kemenristekdikti melalui hibah fundamental DIPA Kopertis Wilayah II tahun anggaran 2016/2017.

\section{DAFTAR PUSTAKA}

[1] Manual Kapasitas Jalan Indonesia, 1997 Departemen Pekerjaan Umum, 1997, Jakarta : Direktorat Jenderal Bina Marga.

[2] Badan Pusat Statistik, 2012, Palembang Dalam Angka, Kota Palembang.

[3] Budiarto, Arif, 2007, Rekayasa Lalu lintas,UNS Surakarta.

[4] Dinas Perhubungan Kota Palembang, 2009, Laporan Akhir Survei Satuan Mobil Penumpang/Lalu lintas Harian Rata-rata Di Kota Palembang 2009, Dishub Palembang.

[5] Hendarto, Sri. dkk. 2001,Dasar-dasar Transportasi, Bandung, Penerbit ITB.

[6] Miro, Fidel, 2004, Perencanaan Transportasi, Jakarta, Penerbit Erlangga.

[7] Morlok, Edward K. 1991, Pengantar Teknik dan Perencanaan Transportasi. Jakarta, Penerbit Erlangga.

[8] Munawar, Ahmad, 2005, Dasar-Dasar Teknik Transportasi, Yogyakarta.

[9] Saodang, Hamirhan, 2004, Konstruksi Jalan Raya, Buku 1 Geometrik Jalan, Nova, Bandung.

[10] Tamin, Ofyar Z. 2008. Perencanaan, Pemodelan dan Rekayasa Transportasi. Bandung, Penerbit ITB. 